\title{
The Pricing of Liquidity Risk and Accounting Quality in Canada
}

\author{
Carl Brousseau ${ }^{1}$ \\ ${ }^{1}$ Associate professor, School of Accounting, Laval University, Canada \\ Correspondence: Carl Brousseau, School of Accounting, Laval University, 2325 rue de la Terrasse, Québec (QC) \\ G1V 0A6 Canada. E-mail : carl.brousseau@ctb.ulaval.ca
}

Received: October 8, 2015

Accepted: October 26, 2015

Online Published: October 28, 2015

doi:10.5430/afr.v4n4p127

URL: http://dx.doi.org/10.5430/afr.v4n4p127

\begin{abstract}
I investigate the pricing of liquidity risk and accounting quality in Canadian equity markets. I report evidence that security prices in Canada are significantly affected by liquidity risk, and that this association is significant throughout the year, with a spike in January. However, despite positive correlation between the accounting quality and liquidity factors, the accounting quality factor is not significantly different from zero except in January, and firm-specific estimates of exposure to the accounting quality factor (i.e. factor betas) have no predictive power for future returns. I conclude that while investments in accounting quality could possibly mitigate liquidity risk, accounting quality is unlikely to have a direct effect on the cost of capital of Canadian firms.
\end{abstract}

Keywords: Accounting quality, Liquidity risk, Asset pricing in Canada

Data Availability: Data used are available from public sources identified in the study.

\section{Introduction}

While the three factors of Fama and French (1993) are often used to model stock returns, their explanatory power is far from perfect, and additional factors have been suggested, such as momentum (Carhart, 1997), liquidity risk (Pastor \& Stambaugh, 2003; Liu, 2006) or information quality (Francis, LaFond, Olsson \& Schipper, 2005; hereafter FLOS) (Note 1). Regarding information quality, topics of interest include the mechanisms through which quality could affect security prices (e.g. Easley \& O'Hara, 2004; Lambert, Leuz \& Verrecchia, 2007, 2012; Lambert \& Verrecchia, 2014), the most appropriate set of empirical constructs to represent quality (e.g. Dechow, Ge \& Schrand, 2010), and the possibility that the observed association between quality and returns might be driven by anomalies or research design rather than risk (e.g. Core, Guay \& Verdi, 2008).

In particular, it is unclear whether both liquidity risk and accounting quality separately affect asset prices. Liquidity risk may arise as a result of a lack of high-quality public information about the firm (Diamond \& Verrecchia, 1991), yet liquidity risk is also affected by other firm-specific factors that may or may not be associated with information quality, such as the firm's market beta, growth rate or capital intensity (Pastor \& Stambaugh, 2003; Ng, 2011). On the other hand, models that address the effect of information quality on the cost of capital (e.g. Easley \& O'Hara, 2004) are sometimes criticized for having unclear or inaccurate predictions regarding whether information quality has a direct or indirect effect on returns, if at all (Lambert et al., 2007; Hughes, Liu \& Liu, 2007). The empirical evidence is also mixed and some have questioned whether the negative association between information quality and realized returns observed in FLOS is a result of risk or a market anomaly (Core et al., 2008; Mashruwala \& Mashruwala, 2011).

In this paper, I investigate the pricing of liquidity risk and accounting quality in Canada. The Canadian setting has at least three features that make such an investigation compelling. First, the Canadian equity market is characterized by a large number of small firms for which liquidity risk is presumably more significant. By comparison, all US firms in Ng's (2011) sample have to be followed by at least three financial analysts, leaving out the smallest firms and potentially underestimating the magnitude of liquidity risk. Second, the Canadian market is two-tiered, with a junior exchange (TSX Venture, or TSXV) characterized by lower trading and a smaller number of participating institutional investors than the main exchange (TSX), making liquidity risk a potentially greater concern. Third, many of Canada's smallest firms are in the resource exploration sector (mining, oil and gas). Investors may assess these firms' information quality in general, and accounting quality in particular, differently than other firms. On the one hand, one could argue that external financial statements are relatively more important for small exploration firms than for other firms because the former are more likely to rely on equity financing than debt, and debtholders may have 
access to alternative information channels, which would reduce pressure for high-quality disclosure. On the other hand, nonfinancial information (e.g. technical exploration or progress reports) could be much more important than financial statements for exploration firms, a large number of which have no revenues and few non-cash assets. In other words, while information quality is likely (value-) relevant for such firms, it is unclear whether accounting quality is as important.

Using a sample of listed firms from 1992 to 2014 and following the methodology in Liu (2006) for the construction of a liquidity risk factor, I document evidence that security prices in Canada are significantly affected by liquidity risk. On average, a liquidity-mimicking factor $(L I Q)$ that is long the least liquid stocks and short the most liquid stocks returns $3.81 \%$ per month, over twice the market risk premium and over ten times (over six times) the size (book-to-market) factor premium. However, subsample analysis shows that exposure to $L I Q$ is largely limited to firms listed on the TSXV, which represent over 50\% of all observations in the sample but only $1.6 \%$ of the average monthly market capitalization. Using a similar methodology and data from firms' annual financial statements, I find that a Canadian accounting quality-mimicking factor $(A Q F)$ that is long in low-quality stocks and short in high-quality stocks returns $0.74 \%$ per month over the same time period, a result entirely due to the January effect: on average, $A Q F$ returns $7.97 \%$ in January but only $0.09 \%$ in all other months. In time-series firm-specific tests, I find strong evidence of commonality between $L I Q$ and $A Q F$ as the explanatory power of either is significantly reduced when the other is introduced. However, in two-stage cross-sectional regressions (2SCSR), I find that the estimate of a firm's liquidity beta has predictive power for future returns, while a firm's accounting quality beta estimate is only positively associated with future January returns. I conclude that liquidity risk is a significant factor affecting security prices in Canada, and that while improvements in accounting quality may mitigate liquidity risk, they are unlikely to have a (direct) systematic effect on stock prices.

This study contributes to the accounting literature in several ways. First, I document the magnitude of liquidity risk in an equity market characterized by a large number of small inherently risky companies with a dedicated venture capital stock exchange. Second, I show that the negative association between accounting quality and stock returns in January persists in a non-US setting. Third, I show that the correlation between accounting quality and liquidity risk is significant throughout the year, but that liqudity risk is more strongly associated with stock returns.

The remainder of the paper is structured as follows. Section 2 reviews the literature. Section 3 discusses the research design, while section 4 describes the sample. Section 5 reports the results, and section 6 concludes.

\section{Literature Review}

\subsection{Liquidity Risk}

Many studies have empirically demonstrated that returns increase with illiquidity (e.g. Amihud \& Mendelson, 1986; Brennan \& Subrahmanyam, 1996; Amihud, 2002; Bekaert, Harvey \& Lundblad, 2007), and theoreticals models have shown how liquidity might be a systematic (i.e. priced) risk factor. For example, in Chien and Lustig (2010), investors are compensated for bearing business cycle-related liquidity risk, and in Holmstrom and Tirole (2001), a stock's sensitivity to marketwide liquidity affects its expected return. Pastor and Stambaugh (2003) use similar arguments to construct a factor based on order flow-induced return reversals and show that the factor has explanatory power beyond the market, size and book-to-market factors of Fama and French (1993), while Liu's (2006) volume-based factor is not only priced, but even subsumes the size and book-to-market effects (Liu, 2006, p. 666).

\subsection{Accounting Quality}

Theoretical models often link information with security prices. In Diamond and Verrecchia (1991), the disclosure of public information for firms with a high level of information asymmetry reduces the cost of capital. In Easley and O'Hara (2004), risk-averse uninformed investors will lower their bids to protect themselves against the probability that they might be dealing with informed traders because they cannot diversify away that risk. In Lambert et al. (2007, 2012) and Hughes, Liu and Liu (2007), accounting quality and information asymmetry can affect prices through a change in the covariation of the firm's cash flows with other firms' cash flows (i.e. beta), and are therefore not priced separately unless beta is measured with error. Recently, Lambert and Verrecchia (2014) show that information has a direct role on the cost of capital when a market is characterized by imperfect competition.

Many empirical papers relate accounting or disclosure quality to the cost of capital. For example, Botosan (1997) finds a positive effect of disclosure on the cost of capital of firms with low analyst following. Francis, LaFond, Olsson and Schipper (2004) investigate various earnings attributes and show that a smoothness measure (Leuz, Nanda \& Wysocki, 2003) and an accrual quality measure (Dechow \& Dichev, 2002) are most strongly associated with the cost of capital. FLOS build on the latter finding and show that $A Q F$ has incremental explanatory power to 
the Fama and French (1993) factors in time-series tests: low-quality firms have a higher cost of capital than high-quality firms, consistent with Easley and O'Hara's (2004) information risk explanation.

However, Core et al. (2008) show that the FLOS results are not robust and that they are driven by a small subset of low-price stocks. $\mathrm{Ng}$ (2011) investigates the role of accounting quality in the determination of firms' exposure to liquidity risk and finds that quality is negatively associated with market risk and liquidity risk. He calls for caution against the generalizability of this result, because quality also seems to have a direct, positive effect on realized returns; the net effect is a positive relationship between accounting quality and realized returns $(\mathrm{Ng}, 2011, \mathrm{p}$. 137-138) (Note 2). Mashruwala and Mashruwala (2011) also cast doubt on the risk explanation by showing that in the US, low-quality firms only earn higher returns in January, a finding they attribute to the tax loss selling hypothesis previously documented in the US (e.g. Roll, 1983; Constantinides, 1984).

The combination of these results raises unanswered questions. Are the results in $\mathrm{Ng}$ (2011) an artifact of the January effect? Conversely, are Mashruwala and Mashruwala's (2011) findings driven by liquidity risk? After controlling for liquidity risk, is there a direct association between accounting quality and stock returns in a setting characterized by a large number of very small firms (Canada)? This study intends to answer these questions.

\section{Research Design}

\subsection{Asset Pricing Tests}

I conduct multiple tests to determine whether accounting quality and liquidity risk are priced in Canada. First, I construct liquidity $(L I Q)$ and accounting quality $(A Q F)$ factor-mimicking portfolios in a similar fashion to Liu (2006) and FLOS. As with Carhart's (1997) momentum factor, these factors are based on a zero-investment trading strategy that is long (short) the least (most) liquid firms for $L I Q$, and long (short) the worst (best) accounting quality firms for $A Q F$. I then compare returns on $L I Q$ and $A Q F$ with those on the three factors of Fama and French (1993): excess return on the market portfolio $\left(M K T R F=R_{M}-R_{f}\right)$, size $(S M B)$ and book-to-market $(H M L)$. This methodology necessitates the creation of factor-mimicking portfolios with data from the Canadian equity market; factor construction is detailed in subsections 3.2 to 3.4 .

Second, as in FLOS, I run firm-specific time-series OLS regressions of contemporaneous excess returns (i.e. returns in excess of the risk-free rate, $R_{j, t}-R_{f, t}$ ) on factor returns. For example, I estimate the following five-factor model for each firm:

$$
R_{j, t}-R_{f, t}=a_{j}+b_{j, M K T R F} M K T R F_{t}+b_{j, S M B} S M B_{t}+b_{j, H M L} H M L_{t}+b_{j, L Q Q} L I Q_{t}+b_{j, A Q F} A Q F_{t}+\varepsilon_{j, t}
$$

As pointed out by Core et al. (2008), a positive regression coefficient implies that firm returns are, on average, positively exposed to a given factor-mimicking strategy, rather than actual evidence of a priced risk factor. Nevertheless, these regressions parallel the size and book-to-market time series tests in Fama and French (1993) and are informative of how the stock price of Canadian firms moves with common factors.

Third, I follow Petkova (2006) and Core et al. (2008) and conduct 2SCSR to test whether LIQ and AQF are priced risk factors in Canada. In the first stage, I estimate multivariate betas from firm-specific time-series OLS regressions such as those described above. In the second stage, I run monthly cross-sectional regressions of excess returns on the factor betas estimated in the first stage using the Fama and MacBeth (1973) procedure:

$$
R_{j, t}-R_{f, t}=\lambda_{0}+\lambda_{1} b_{j, M K T R F}+\lambda_{2} b_{j, S M B}+\lambda_{3} b_{j, H M L}+\lambda_{4} b_{j, L I Q}+\lambda_{5} b_{j, A Q F}+u_{j, t}
$$

In this regression, a positive coefficient indicates that the corresponding factor is priced, either through risk or mispricing. Because the first-stage regression uses the entire time series that imply static firm-specific betas throughout the estimation period, for additional tests I repeat first-stage estimation with the time series prior to the estimation date only (i.e. expanding windows as in Pastor and Stambaugh (2003) and Ng (2011)).

\subsection{Factor Construction: Size, Book-to-market, and Market Risk Premium}

I construct the Canadian MKTRF, SMB and $H M L$ factor-mimicking portfolios in a similar fashion to Fama and French (1993, p. 8-10); for brevity, I only describe Canada-specific design choices here. Market (accounting) data are from the Compustat North America Security Monthly (Fundamentals Annual) database. The value-weighted (equal-weighted) market risk premium $M K T R F_{v}\left(M K T R F_{e}\right)$ is obtained by substracting the return to the three-month Canadian government treasury bills from the value-weighted (equal-weighted) return to the market portfolio. Size group assignments (small and big) are based on the median market capitalization of the TSX exchange (Note 3), while book-to-market groups consist of the top 30\%, middle $40 \%$ and bottom $30 \%$ of all firms with a nonnegative book value. Constructed as in Fama and French (1993), the size factor SMB is a book-to-market-invariant size premium, while the book-to-market factor $H M L$ is a size-invariant book-to-market premium. 


\subsection{Factor Construction: Liquidity Risk}

I follow Liu (2006) to construct the liquidity risk factor. Liu (2006) develops a firm-specific liquidity measure LM12 that is based on the number of zero volume days over the previous 12 months, with share turnover as a tiebreaker among the most liquid stocks:

$$
\text { LM12 }=[\text { ZVDays }+(1 / \text { TURN }) / 500] * 21 / \text { NoTD }
$$

where ZVDays is the number of zero volume days $(C H S T R D=0)$ for a stock, TURN is the sum of daily share turnover (Compustat CSHTRD/CSHOM) and NoTD is the number of trading days, all over the previous 12 months. The deflator in the second term (500) is chosen to ensure that the second term within brackets is strictly contained between zero and one. For each month, the liquidity factor-mimicking portfolio, $L I Q$, is the difference between the equal-weighted returns of the low-liquidity $(L L)$ and high-liquidity $(H L)$ portfolios (Note 4$)$, where $L L(H L)$ is composed of firms in the top (bottom) three deciles of LM12: (Note 5)

$$
L I Q_{t}=L L_{t}-H L_{t}
$$

\subsection{Factor Construction: Accounting Quality}

I follow FLOS to construct the accounting quality factor. The factor is based on the Dechow and Dichev (2002) measure of accrual quality $(A Q)$, as augmented by McNichols (2002). The rationale behind $A Q$ is that accounting accruals are associated with past, current and future operating cash flows, growth and capital intensity, and that accrual volatility unexplained by these factors indicates low accounting quality. In main tests, because of the limited availability of data from the statement of cash flows in the early years of the sample, operating cash flows are inferred from balance sheet accruals and depreciation (all variables are from Compustat Fundamentals Annual and are deflated by average assets) (Note 6):

$$
\begin{gathered}
T C A_{t}=\left(\Delta A C T_{t}-\triangle C H E_{t}-\triangle L C T_{t}+\Delta D L C_{t}\right) \\
C F O_{t}=I B_{t}-T C A_{t}+D E P_{t}
\end{gathered}
$$

To calculate $A Q$, I run yearly industry cross-sectional regressions of current accruals on operating cash flows and controls:

$$
T C A_{j, t}=\alpha+\beta_{1} C F O_{j, t-1}+\beta_{2} C F O_{j, t}+\beta_{3} C F O_{j, t+1}+\beta_{4} \triangle S A L E S_{j, t}+\beta_{5} P P E_{j, t}+\varepsilon_{j, t}
$$

where TCA and $C F O$ are defined above, $\triangle S A L E S$ is year-on-year sales growth, and PPE is property, plant and equipment as a percentage of average assets. At the firm level, accrual quality $(A Q)$ is the five-year standard deviation of the residual from that regression. $A Q$ is calculated with a one-year lag as the regression in Equation (7) uses one-year-ahead cash flows $\left(C F O_{j, t+1}\right)$ :

$$
A Q_{j, t}=\sigma\left(\varepsilon_{j, k}\right), k \in[t-5, t-1]
$$

For each month, the accounting quality factor-mimicking portfolio, $A Q F$, is the difference between the equal-weighted returns of the low-accounting-quality $(L A Q)$ and high-accounting-quality $(H A Q)$ portfolios, where $L A Q(H A Q)$ is composed of firms in the best (worst) 2 deciles of $A Q$ based on the latest available data (Note 7):

$$
A Q F_{t}=L A Q_{t}-H A Q_{t}
$$

\section{Sample and Descriptive Statistics}

To construct all factors except $A Q F$, I use data for all Canadian exchange-listed firms (EXCHG between 6 and 10) with common stocks $(T P C I=0)$ on Compustat Security Monthly for 1992-2014. For firms with multiple traded common stock classes (IID), I keep the class with the highest market capitalization, defined as stock price PRCCM times shares outstanding CSHOM (Note 8). To mitigate the effect of outliers and data errors on the results, I follow Ince and Porter (2006) and Papanastasopoulos (2014) and exclude returns of two consecutive months if the return (TRTIM) of either of those months is higher than $300 \%$ or lower than $-50 \%$. 
Table 1. Sample selection

\begin{tabular}{lrr}
\hline Description & $\begin{array}{r}\text { Firm-month } \\
\text { observations } \\
\text { (returns) }\end{array}$ & $\begin{array}{c}\text { Firm-year } \\
\text { observations } \\
\text { (accounting) }\end{array}$ \\
\hline Canadian observations on Compustat North America, 1992-2014 & 659448 & 33741 \\
Minus : Financial Industry (GSECTOR=40) & 51036 & 6783 \\
Minus : Missing or extreme data & 39135 & 1927 \\
Sample for factor construction (except $\boldsymbol{A Q F}$ ) and asset pricing tests & $\mathbf{5 6 9 2 7 7}$ & $\mathbf{2 5 0 3 1}$ \\
Minus: Missing $A Q$ data & 489675 & 18899 \\
Sample for $\boldsymbol{A Q F}$ factor construction & $\mathbf{7 9 6 0 2}$ & $\mathbf{6 9 4 3}$ \\
\hline
\end{tabular}

To construct $A Q F$, I include all nonfinancial $\left(G S E C T O R^{\wedge}=40\right)$ Canadian firms in the Compustat North America Fundamentals Annual database. Because $A Q$ requires eight years of data (Note 9), I use annual accounting data beginning in 1984. I use two-digit NAICS (GSECTOR) to define industries and require at least 10 observations per year to calculate $A Q$. As shown in Table 1, the final sample for factor construction (except $A Q F$ ) and asset pricing tests consists of 569277 firm-month observations, while the final sample for accounting quality factor construction consists of 79602 firm-month observations (Note 10).

Table 2. Descriptive statistics

Panel A: Monthly market data (n=569 277 except for $M V$ where $n=501843)$

\begin{tabular}{|c|c|c|c|c|c|c|c|}
\hline Variables & Mean & STD & $\mathrm{P} 10$ & $\mathrm{P} 25$ & P50 & P75 & $\mathrm{P} 90$ \\
\hline$R E T$ & 0.022 & 0.267 & -0.226 & -0.111 & -0.000 & 0.095 & 0.277 \\
\hline ZEROVOL & 5.6 & 6.6 & 0.0 & 0.0 & 2.0 & 10.0 & 17.0 \\
\hline TURN & 0.033 & 0.049 & 0.000 & 0.003 & 0.015 & 0.041 & 0.084 \\
\hline$M V(C A \$ M M)$ & 495.4 & 3088.3 & 1.3 & 4.2 & 19.6 & 118.0 & 630.7 \\
\hline \multicolumn{8}{|c|}{ Panel B: Annual accounting data $(n=6943)$} \\
\hline Variables & Mean & STD & $\mathrm{P} 10$ & $\mathrm{P} 25$ & $\mathrm{P} 50$ & P75 & $\mathrm{P} 90$ \\
\hline$A Q_{B S}$ & 0.077 & 0.081 & 0.017 & 0.028 & 0.048 & 0.092 & 0.176 \\
\hline GROWTH & 0.040 & 0.236 & -0.160 & -0.023 & 0.026 & 0.120 & 0.270 \\
\hline$\sigma(C F O)$ & 0.227 & 0.892 & 0.026 & 0.044 & 0.080 & 0.153 & 0.307 \\
\hline$\sigma(S A L E S)$ & 0.224 & 0.291 & 0.023 & 0.067 & 0.146 & 0.272 & 0.470 \\
\hline $\log (O P C Y C L E)$ & 4.353 & 1.426 & 3.388 & 4.132 & 4.611 & 5.027 & 5.439 \\
\hline LOSSYRS & 0.356 & 0.371 & 0.000 & 0.000 & 0.200 & 0.600 & 1.000 \\
\hline
\end{tabular}

Table 2 Panel A (B) reports the mean, standard deviation deviation and $10^{\text {th }}, 25^{\text {th }}, 50^{\text {th }}, 75^{\text {th }}$ and $90^{\text {th }}$ percentiles of the sample distribution of market variables for 569277 firm-month observations (accounting variables for the 6943 firm-year observations with sufficient data to calculate $A Q$ ) (Note 11). In Table 2 Panel A, average monthly stock return was $2.2 \%$ for $1992-2014$, with a distribution that was considerably skewed (the median was essentially zero). The average number of zero volume days per month was 5.6; given that there are around 21 trading days per month, this implies that on any given day, over $25 \%$ of listed Canadian firms went without any trade. Average monthly turnover $(T U R N)$ was 0.033 , and average market capitalization $(M V)$ was 495.4 million dollars (CA $\$)$. Variations in all of these numbers were driven by the large number of comparatively small firms on the TSX Venture Exchange. For example, the median ZEROVOL for TSXV firms (untabulated) was 7, compared to 0 for TSX firms, while the average $M V$ was more than 50 times larger for TSX firms than TSXV firms (1003.8M\$ compared to 19.6M\$).

In Table 2 Panel $\mathrm{B}$, mean $A Q$ was 0.077 , higher (worse quality) than AQ studies with US data (FLOS; Ng, 2011) but unsurprising given the large number of small firms listed in Canada and the well-known negative association between size and accounting quality (Dechow \& Dichev, 2002). Trend analysis (untabulated) suggests that $A Q$ increased over time. The additional variables are identified in FLOS as "innate" determinants of accrual quality. On average, sales growth was $4 \%$ per year over the full period, and the five-year standard deviation of both cash flows and sales was over $22 \%$ of assets. The natural logarithm of the operating cycle was 4.353 on average, which corresponds to 77.7 days, while around $35 \%$ of firm-year observations in the sample were loss years. 


\section{Results}

\subsection{Monthly Factor Returns}

Table 3. Monthly factor returns

Panel A: Descriptive statistics

\begin{tabular}{llrrrrrc}
\hline Factor & $\mathrm{N}$ & Mean $(\%)$ & \multicolumn{1}{c}{ STD } & \multicolumn{1}{l}{ Min } & Median & Max & \multicolumn{1}{c}{ t-stat } \\
\hline MKTRF $_{v}$ & 276 & 1.49 & 4.09 & -17.16 & 1.75 & 13.28 & $6.06^{* * * *}$ \\
MKTRF & 276 & 1.88 & 6.15 & -21.96 & 2.08 & 24.16 & $5.07 * * *$ \\
$S M B$ & 276 & 0.32 & 3.43 & -11.30 & 0.11 & 16.37 & 1.55 \\
$H M L$ & 276 & 0.61 & 3.58 & -14.28 & 0.60 & 13.62 & $2.82^{* * *}$ \\
LIQ & 276 & 3.81 & 4.38 & -8.55 & 3.25 & 27.68 & $14.44^{* * *}$ \\
AQF & 276 & 0.74 & 5.66 & -13.60 & 0.10 & 29.13 & $2.19^{* *}$ \\
\hline
\end{tabular}

Panel B: Pearson correlation matrix

\begin{tabular}{llcccccc}
\hline & & 1 & 2 & 3 & 4 & 5 & 6 \\
\hline 1 & MKTRF $_{v}$ & & & & & & \\
2 & MKTRF & & 0.74 & & & & \\
3 & $S M B$ & 0.10 & 0.63 & & & & \\
4 & HML & -0.24 & -0.12 & -0.13 & & & \\
5 & LIQ & -0.30 & 0.10 & 0.39 & 0.10 & & \\
6 & AQF & 0.26 & 0.56 & 0.59 & -0.27 & 0.24 & \\
\hline
\end{tabular}

Table 3 Panel A presents descriptive statistics of monthly factor returns for 1992-2014 (276 months), along with the test statistic ( $t$-stat) that the mean is different from zero (Note 12). The value-weighted market risk premium, $M K T R F_{v}$, was $1.49 \%$ per month on average for the sample period, with a median of $1.75 \%$. The equal-weighted market premium, $M K T R F_{e}$, was slightly higher at $1.88 \%$ per month on average (median: $2.08 \%$ ). The size factor, $S M B$, was only $0.32 \%$ per month on average and was the only factor not significantly different from zero at conventional levels. The book-to-market factor, $H M L$, was $0.61 \%$ per month on average. Results for the liquidity factor, $L I Q$, are striking: firms in the low-liquidity portfolio outperformed those in the high-liquidity portfolio by $3.81 \%$ per month on average, or a compounded $56.61 \%$ per year. The performance of $L I Q$ was also significantly positive for 22 years out of 23 (untabulated); by comparison, $M K T R F_{v}\left(M K T R F_{e}\right)$ were significantly positive for only 12 (7) years. The accounting quality factor $A Q F$ was a significant $0.74 \%$ per month on average, although the median $(0.10 \%)$ was close to zero.

Despite $L I Q$ being a "traded" factor in theory in the sense that it represents the return to a portfolio that is long in low-liquidity stocks and short in high-liquidity stocks, it may not be a practical trading strategy. While the short side of the strategy can likely be achieved as large liquid stocks can generally be borrowed cheaply (D'Avolio, 2002), an investment in firms on the long side of $L I Q$ would imply significant transaction costs, and firms may be so thinly traded that any significant purchase could move their price up, negating some of the profits to the strategy (Note 13).

The Pearson correlation analysis in Tabel 3 Panel B suggests a strong commonality between $M K T R F_{e}, S M B, L I Q$ and $A Q F$ (Note 14). For example, the correlation between $S M B$ and $A Q F$ is 0.59 , which is unsurprising given the negative association between size and accounting quality mentioned earlier. The correlation between $L I Q$ and $A Q F$ is also significant at 0.24 , suggesting that some (but not all) of the $L I Q$ premium may be driven by accounting quality, or alternatively that $A Q F$ is affected by value-relevant characteristics that also affect $L I Q$. 
Table 4. Factor returns by calendar month

Panel A: Mean returns by calendar month

\begin{tabular}{|c|c|c|c|c|c|c|c|c|c|c|c|c|}
\hline Factor & Jan & & Feb & & Mar & & Apr & & May & & Jun & \\
\hline$M K T R F_{v}$ & 2.08 & $* *$ & 2.05 & $* *$ & 1.48 & $*$ & 1.94 & $* * *$ & 1.83 & $* *$ & 0.10 & \\
\hline$S M B$ & 3.98 & $* * *$ & 1.96 & $* *$ & -0.39 & & -1.14 & & 0.79 & & -0.23 & \\
\hline$H M L$ & 0.08 & & 0.51 & & 1.51 & $* *$ & 2.34 & $* * *$ & 1.29 & & 1.60 & $* *$ \\
\hline$L I Q$ & 7.20 & $* * *$ & 6.54 & $* * *$ & 5.04 & $* * *$ & 3.00 & $* * *$ & 3.68 & $* * *$ & 4.05 & $* * *$ \\
\hline$A Q F$ & 7.97 & $* * *$ & 3.20 & $* *$ & 0.24 & & -2.03 & $* *$ & 0.49 & & -1.33 & \\
\hline Factor & Jul & & Aug & & Sep & & Oct & & Nov & & Dec & \\
\hline$M K T R F_{v}$ & 1.27 & $*$ & 0.75 & $* *$ & -0.25 & & 1.75 & & 1.77 & $*$ & 3.15 & $* * *$ \\
\hline$S M B$ & -0.50 & & -0.18 & & 1.39 & $* *$ & -1.32 & $* *$ & -1.58 & $* *$ & 1.07 & $*$ \\
\hline$H M L$ & 0.82 & & 0.00 & & -0.13 & & -0.83 & & -0.06 & & 0.17 & \\
\hline$L I Q$ & 1.72 & $* * *$ & 2.92 & $* * *$ & 3.96 & $* * *$ & 2.63 & $* * *$ & 3.66 & $* * *$ & 1.30 & \\
\hline$A Q F$ & -0.42 & & -0.33 & & 1.17 & & -1.28 & & 0.33 & & 0.91 & \\
\hline
\end{tabular}

Panel B: January vs. non-January Pearson correlations

\begin{tabular}{lllll|lll}
\hline & & \multicolumn{3}{c|}{ January } & \multicolumn{3}{c}{ Non-January } \\
\hline & & 1 & 2 & 3 & 1 & 2 & 3 \\
\hline 1 & $S M B$ & & & & & & \\
2 & LIQ & 0.55 & & & 0.32 & \\
3 & AQF & 0.45 & -0.17 & & 0.55 & 0.22 \\
\hline
\end{tabular}

Table 4 Panel A shows average monthly factor returns by calendar month for 1992-2014. This decomposition is relevant for multiple reasons. First, Mashruwala and Mashruwala (2011) document that their version of $A Q F$ yields significantly positive returns in January but not in other months, a phenomenon driven by small stocks and which they attribute to the tax loss selling hypothesis, inconsistent with the information risk explanation. The question is whether this is also true in Canada, which has a broadly similar tax regime but a much larger proportion of small natural resource companies, whose accounting numbers may be more or less tightly linked to tax loss selling. Second, $\mathrm{Ng}$ (2011) shows that accounting quality is associated with liquidity risk. In the context of this table, this begs the question whether the relatively large monthly factor returns for $L I Q$ documented in Table 2 Panels A and B are driven by the January effect (Note 15). Third, to my knowledge, there is no recent evidence on the January effect in Canada (Note 16).

Consistent with Athanassakos (1992), Canadian small firms significantly outperform large firms in January. At 3.98\% on average, $S M B$ was twice as large in January as in any other month; this outperformance of small stocks in January explains a large part of the superior average returns of equal-weighted $M K T R F_{e}$ compared to value-weighted $M K T R F_{v}$. Also, consistent with Amihud (2002), the liquidity risk premium was highest in January at $7.20 \%$ on average, but $L I Q$ was also significantly positive in every other month except December. Finally, consistent with US evidence in Mashruwala and Mashruwala (2011), $A Q F$ was highest in January at 7.97\%; it was also positive in February but was insignificant in all other months except April, where it was negative and significant at the $5 \%$ level. In summary, while $S M B, L I Q$ and $A Q F$ were all positive in January, only $L I Q$ carried a positive premium throughout the rest of the year.

To further investigate the potential overlap between $S M B, L I Q$ and $A Q F$, Table 4 Panel B reports correlation coefficients for January (first three columns) and all months except January (last three columns) (Note 17). The positive correlation of $S M B$ with all three other factors in confirms that the liquidity and accounting quality factors are significantly driven by small firms. However, the size component of the liquidity risk premium is significantly smaller in non-January months, as indicated by the positive correlation in 0.55 in January compared to 0.32 in other months. Also, the correlation between liquidity risk and accounting quality is insignificant in January, while it is 
positive but relatively small in other months. This indicates that the January effect captured by $A Q F$ is not liquidity-driven. The evidence is also consistent with the positive association between accounting quality and liquidity risk documented in $\mathrm{Ng}$ (2011). Taken together, these results suggest that the accounting quality pricing effects independently reported in Mashruwala and Mashruwala (2011) and $\mathrm{Ng}$ (2011) are not driven by the same phenomena.

\subsection{Firm-specific Time Series Regressions}

In this section, I provide evidence that firm-specific returns are exposed to the common factors described in the previous section. As described in subsection 3.1, I run firm-specific regressions of excess monthly returns on contemporaneous factors, and then tabulate averages of coefficients across all firms. To the extent that average factor returns are influenced by a large number of firms, the average coefficient will be significant; on the other hand, if average factor returns are essentially made up of noise, the average coefficient will be indistinguishable from zero. This does not imply that firm-specific exposure to those factors (i.e. betas) has any predictive power for future returns, which will be investigated in the next subsection.

Table 5. Firm-specific time-series regressions

\begin{tabular}{|c|c|c|c|c|c|c|c|c|c|c|}
\hline Model & (1) & & $(2)$ & & (3) & & (4) & & (5) & \\
\hline Variable & Coeff. & t-stat & Coeff. & t-stat & Coeff. & t-stat & Coeff. & t-stat & Coeff. & t-stat \\
\hline Intercept & 0.04 & 0.91 & -0.69 & -1.68 & -0.02 & -0.51 & -0.81 & -11.21 & -0.70 & -9.48 \\
\hline$M K T R F_{v}$ & 1.06 & 77.94 & 1.18 & 79.92 & 1.03 & 74.50 & 1.11 & 73.09 & 1.10 & 71.36 \\
\hline$S M B$ & 1.09 & 61.48 & 0.99 & 56.25 & 0.93 & 45.85 & 0.87 & 44.88 & 0.84 & 43.99 \\
\hline$H M L$ & 0.08 & 5.63 & 0.03 & 2.16 & 0.14 & 9.08 & 0.11 & 7.21 & 0.13 & 8.42 \\
\hline$L I Q$ & & & 0.28 & 17.10 & & & 0.18 & 11.02 & 0.13 & 7.75 \\
\hline$A Q F$ & & & & & 0.18 & 15.42 & 0.14 & 11.96 & 0.10 & 6.91 \\
\hline$L I Q * A Q F$ & & & & & & & & & 0.01 & 5.21 \\
\hline
\end{tabular}

$\begin{array}{llllll}\text { Average adj- } R^{2} & 0.13 & 0.15 & 0.15 & 0.16 & 0.18\end{array}$

Table 5 presents the mean of the 5197 firm-specific regressions with at least 12 monthly returns over 1992-2014, along with the t-statistic that the mean coefficient is equal to zero; the last row shows the average adjusted $R^{2}$ of the 5197 regressions. Model 1 reports results for the three-factor model of Fama and French (1993), while Models 2 to 5 add various combinations of $L I Q$ and $A Q F$. Model 1 results are broadly similar to US results in FLOS (p. 314, Table 3 ) and Core et al. (2008, p.7, Table 2). The average (three-factor) market beta was 1.03 . On average, Canadian firms had significant exposure (1.07) to the size factor, despite the earlier result (Table 3 Panel A) that the size premium itself was insignificant over the sample period. Average exposure to the book-to-market factor was relatively small at 0.12. In Models 2 to 4, the coefficients on $L I Q$ and $A Q F$ are positive and significant, suggesting positive average exposure to the liquidity and accounting quality mimicking factors. Model 5 adds an interaction term between $L I Q$ and $A Q F$; an interpretation is that it measures how exposure to $L I Q$ increases as exposure to $A Q F$ also increases. Results show complementarity between $L I Q$ and $A Q F$, and all three relevant coefficients ( $L I Q, A Q F$ and $L I Q * A Q F$ ) are positive and significant. Importantly, when the interaction term is included, the magnitude of the coefficient on $L I Q(A Q F)$ decreases by $19 \%$ (40\%), from 0.26 to 0.21 ( 0.20 to 0.12 ). A comparison between Models 1 and 5 also shows a drop in $S M B$ from 1.07 to 0.81 when $L I Q, A Q F$ and the interaction term are introduced, suggesting that size may in part be a noisy substitute for omitted value-relevant variables such as liquidity and accounting quality. Additional tests (untabulated) of Model 5 suggest that TSXV firms had a higher market beta (1.17 vs. 1.03) and were significantly more exposed to the size (1.01 vs. 0.67$)$, liquidity $(0.32$ vs. -0.05$)$ and accounting quality $(0.14$ vs. 0.06$)$ factors, and that on average, firms were not significantly differently exposed to the liquidity and accounting quality factors in January than in other months.

\subsection{Two-stage Cross-sectional Regressions}

Core et al. (2008) argue that contemporaneous association between common factors and excess returns is insufficient to conclude that the common factor is priced, and suggest a two-stage cross-sectional regression procedure also used by Petkova (2006). In the first stage, firm-specific betas are obtained in a manner similar to the previous section; in 
the second stage, 276 monthly cross-sectional regressions of excess returns on first-stage betas are estimated. I use two different estimation windows in the first stage (see subsection 3.1), and report second-stage results in Table 6.

Table 6. Cross-sectional regressions of excess returns on factor betas

Panel A: Full period betas

\begin{tabular}{|c|c|c|c|c|c|c|c|c|c|c|}
\hline Model & (1) & & $(2)$ & & (3) & & (4) & & (5) & \\
\hline Variable & Coeff. & t-stat & Coeff. & t-stat & Coeff. & t-stat & Coeff. & t-stat & Coeff. & t-stat \\
\hline Intercept & 1.00 & 43.04 & 1.00 & 45.06 & 1.01 & 43.93 & 1.00 & 46.45 & 1.00 & 47.47 \\
\hline$b\left(M K T R F_{v}\right)$ & 1.59 & 6.02 & 1.59 & 6.03 & 1.61 & 6.11 & 1.60 & 6.09 & 1.60 & 6.13 \\
\hline$b(S M B)$ & 0.35 & 1.50 & 0.35 & 1.53 & 0.35 & 1.52 & 0.36 & 1.58 & 0.36 & 1.63 \\
\hline$b(H M L)$ & 0.59 & 2.43 & 0.59 & 2.47 & 0.59 & 2.44 & 0.60 & 2.52 & 0.61 & 2.63 \\
\hline$b(L I Q)$ & & & 3.77 & 12.76 & & & 3.79 & 12.76 & 3.77 & 12.81 \\
\hline$b(A Q F)$ & & & & & 0.87 & 2.32 & 0.86 & 2.33 & 0.86 & 2.34 \\
\hline$b(L I Q * A Q F)$ & & & & & & & & & 8.97 & 2.71 \\
\hline Average adj- $R^{2}$ & 0.06 & & 0.06 & & 0.07 & & 0.07 & & 0.08 & \\
\hline \multicolumn{11}{|c|}{ Panel B: Historical betas } \\
\hline Model & (1) & & (2) & & (3) & & (4) & & (5) & \\
\hline Variable & Coeff. & t-stat & Coeff. & t-stat & Coeff. & t-stat & Coeff. & t-stat & Coeff. & t-stat \\
\hline Intercept & 0.00 & 0.23 & 0.00 & 0.13 & 0.01 & 0.43 & 0.01 & 0.37 & 0.01 & 0.43 \\
\hline$b\left(M K T_{v}\right)$ & -0.26 & -3.19 & -0.27 & -3.44 & -0.24 & -2.96 & -0.25 & -3.22 & -0.25 & -3.30 \\
\hline$b(S M B)$ & 0.04 & 0.46 & 0.02 & 0.25 & 0.03 & 0.42 & 0.01 & 0.15 & 0.03 & 0.40 \\
\hline$b(H M L)$ & 0.16 & 2.31 & 0.17 & 2.42 & 0.16 & 2.32 & 0.17 & 2.45 & 0.17 & 2.45 \\
\hline$b(L I Q)$ & & & 0.30 & 2.91 & & & 0.31 & 3.03 & 0.33 & 3.32 \\
\hline$b(A Q F)$ & & & & & -0.08 & -0.74 & -0.10 & -0.95 & -0.06 & -0.56 \\
\hline$b(L I Q * A Q F)$ & & & & & & & & & -0.40 & -0.64 \\
\hline Average adj- $R^{2}$ & 0.01 & & 0.01 & & 0.01 & & 0.02 & & 0.02 & \\
\hline
\end{tabular}

For Table 6 Panel A, the first stage firm-specific betas were estimated for 1992-2014 using the corresponding firm-specific regressions used to construct Table 4. For Table 6 Panel B, the first stage estimation window was the period prior to the second-stage monthly regression only. For example, for the monthly cross-sectional regression of March 2003, first-stage betas were estimated over data from January 1992 to February 2003. In both panels, reported figures for each variable are average coefficients over the 276 monthly regressions, while $t$-statistics are based on the time series of coefficients, as in Fama and MacBeth (1973). In other words, Panel A uses a longer data set for first stage estimation, but suffers from look-ahead-bias.

Table 6 Panel A results are broadly consistent with the time series results in Table 5: regardless of the model used, all factors are positively related to returns at the $1 \%$ significance level (except $b(S M B)$ at the $10 \%$ level). In particular, Models 2, 4 and 5 show that the beta coefficient most strongly associated with returns is the liquidity beta, $b(L I Q)$. In Model 5, an increase of one unit of a firm's liquidity beta (for example a increase in $b(L I Q)$ from 1.50 to 2.50 ) increases the realized monthly return by $3.77 \%$, while an increase of one unit of $b(A Q)$ increases monthly return by $0.86 \%$.

Table 6 Panel B produces results that are more in line with Petkova (2006) and Core et al. (2008), with a weaker explanatory power and insignificant results for some of the variables (Note 18). Notably, when betas are only estimated using historical betas (i.e. when return realizations subsequent to the second-stage monthly regression period are excluded), the market risk premium is significantly negative at $-0.24 \%$ to $-0.27 \%$ per month. According to those results, there is no size premium in Canada, but both the book-to-market and liquidity factors have a significantly positive association with realized excess returns. In particular, the coefficient on $b(L I Q)$ in Model (2) 
implies a liquidity risk premium of $0.37 \%$ per month by unit of liquidity beta. As for accounting quality, results are this time consistent with Core et al. (2008), and there is no evidence that $b(A Q F)$ is associated with excess returns. Additional tests (untabulated) confirm Mashruwala and Mashruwala's (2011) result that accounting quality is positively associated with stock returns in January but not in other months, as the coefficient on $b(A Q F)$ is positive and significant in January (e.g. 1.41 in Model 3) but is actually negative and at least marginally significant in other months (e.g. - 0.21 in Model 3).

In summary, results in Table 6 show strong evidence that liquidity risk is associated with security prices in Canada, while direct evidence of a positive association between accounting quality and returns is restricted to the month of January.

\section{Conclusion}

In this paper, I investigate the pricing of liquidity risk and accounting quality in Canada. I report evidence that security prices in Canada are significantly affected by liquidity risk, and that this association is significant throughout the year, despite a positive correlation with the well-known January effect concentrated in small firms. By contrast, despite evidence that accounting quality is negatively associated with January stock returns and the significant positive correlation between the liquidity risk factor and the accounting quality factor, accounting quality is directly associated with returns in January only. In other words, the potential effect of accounting quality on the cost of capital may be restricted to its indirect role in mitigating liquidity risk.

This study suffers from limitations. First, results may be contingent on the measure of accounting quality used in this paper. By construction, $A Q$ excludes the youngest firms as its calculation requires eight years of annual accounting data. As a result, $A Q F$ could be underestimated, or at the very least measured with error. I am not aware of a reliable accounting quality measure based on quarterly data; such a measure would reduce the time series required for a firm to enter the factor-mimicking portfolio. Alternatively, short-term measures such as abnormal accruals or the one-year residual from Equation (7) could be used, but this could result in additional noise. Second, Dechow and Dichev (2002) and FLOS show that $A Q$ is correlated with many economic factors such as firm size, volatility, or the length of the firm's operating cycle; a factor based on some measure of discretionary accrual quality could yield different results (Note 19). Third, accounting quality may or may not be a substitute to the quality of other financial and non-financial documents, and controlling for the quality of such documents could yield different results regarding the association of accounting quality with stock prices. This could be especially important in the Canadian setting dominated by mining and oil and gas firms, but would require extensive manual data collection and content analysis.

These results also provide opportunities for future research. Research is sparse on the determinants of liquidity risk, especially in Canadian equity markets, and the role of information quality on liquidity risk has not been demonstrated outside of large US firms. The role of accounting standards (i.e. aggregate accounting quality) on aggregate (marketwide) liquidity risk is also not well understood.

\section{References}

Amihud, Y. (2002). Illiquidity and stock returns: Cross-section and time-series effects. Journal of Financial Markets, 5, 31-56. http://dx.doi.org/10.1016/S1386-4181(01)00024-6

Amihud, Y. \& Mendelson, H. (1986). Asset pricing and the bid-ask spread. Journal of Financial Economics 17, 223-249. http://dx.doi.org/10.1016/0304-405X(86)90065-6

Athanassakos, G. (1992). Portfolio rebalancing and the January effect in Canada. Financial Analysts Journal, 48, 67-78. http://dx.doi.org/10.2469/faj.v48.n6.67

Bekaert, G., Harvey, C. \& Lundblad, C. (2007). Liquidity and expected returns: Lessons from emerging markets. Review of Financial Studies 20, 1783-1831. http://dx.doi.org/10.1093/rfs/hhm030

Berges, A., McConnell, J. \& Schlarbaum, G. (1984). The turn-of-the-year in Canada. Journal of Finance, 39, 185-192. http://dx.doi.org/10.1111/j.1540-6261.1984.tb03867.x

Brennan, M. \& Subrahmanyam, A. (1996). Market microstructure and asset pricing: On the compensation for illiquidity in stock returns. Journal of Financial Economics 41, 441-464. http://dx.doi.org/10.1016/0304-405X(95)00870-K

Carhart, M. (1997). On persistence in mutual fund performance. Journal of Finance, 52, 57-82. http://dx.doi.org/10.1111/j.1540-6261.1997.tb03808.x 
Chien, Y. \& Lustig, H. (2010). The market price of aggregate risk and the wealth distribution, Review of Financial Studies 23, 1596-1650. http://dx.doi.org/10.1093/rfs/hhp079

Constantinides, G. (1984). Optimal stock trading with personal taxes: Implications for prices and the abnormal January returns. Journal of Financial Economics, 13, 65-89. http://dx.doi.org/10.1016/0304-405X(84)90032-1

Core, J., Guay, W. \& Verdi, R. (2008). Is accruals quality a priced risk factor? Journal of Accounting and Economics, 46, 2-22. http://dx.doi.org/10.1016/j.jacceco.2007.08.001

D'Avolio, G. (2002). The market for borrowing stock. Journal of Financial Economics, 66, 271-306. http://dx.doi.org/10.1016/S0304-405X(02)00206-4

Dechow, P. \& Dichev, I. (2002). The quality of accruals and earnings: The role of accrual estimation errors. The Accounting Review, 77 (Supplement), 35-59. http://dx.doi.org/10.2308/accr.2002.77.s-1.35

Dechow, P., Ge, W. \& Schrand, C. (2010). Understanding earnings quality: A review of the proxies, their determinants and their consequences. Journal of Accounting and Economics 50, 344-401. http://dx.doi.org/10.1016/j.jacceco.2010.09.001

Diamond, D. \& Verrecchia, R. (1991). Disclosure, liquidity, and the cost of capital. Journal of Finance, 46, 1325-1359. http://dx.doi.org/10.1111/j.1540-6261.1991.tb04620.x

Easley, D. \& O'Hara, M. (2004). Information and the cost of capital. Journal of Finance, 59, 1553-1583. http://dx.doi.org/10.1111/j.1540-6261.2004.00672.x

Fama, E. \& MacBeth, J. (1973). Risk, return and equilibrium: Empirical tests. Journal of Political Economy, 81, 607-636. http://dx.doi.org/10.1086/260061

Fama, E. \& French, K. (1993) Common risk factors in the returns on stocks and bonds. Journal of Financial Economics, 33, 3-56. http://dx.doi.org/10.1016/0304-405X(93)90023-5

Francis, J., LaFond, R., Olsson, P. \& Schipper, K. (2004). Costs of equity and earnings attributes. The Accounting Review 79, 967-1010. http://dx.doi.org/10.2308/accr.2004.79.4.967

Francis, J., LaFond, R., Olsson, P. \& Schipper, K. (2005). The market pricing of accruals quality. Journal of Accounting and Economics, 39, 295-327. http://dx.doi.org/10.1016/j.jacceco.2004.06.003

Holmstrom, B. \& Tirole, J. (2001). LAPM: A liquidity-based asset pricing model. Journal of Finance 56, 1837-1867. http://dx.doi.org/10.1111/0022-1082.00391

Hribar, P. \& Collins, D. (2002). Errors in estimating accruals: Implications for empirical research. Journal of Accounting Research, 40, 105-134. http://dx.doi.org/10.1111/1475-679X.00041

Hughes, J., Liu, J. \& Liu, J. (2007). Information asymmetry, diversification, and cost of capital. The Accounting Review, 82, 705-729. http://dx.doi.org/10.2308/accr.2007.82.3.705

Ince, O. \& Porter, R. B. (2006). Individual equity return data from Thomson Datastream: Handle with care! The Journal of Financial Research, 29, 463-479. http://dx.doi.org/10.1111/j.1475-6803.2006.00189.x

L'Her, J.-F., Masmoudi, T. \& Suret, J.-M. (2004). Evidence to support the four-factor pricing model from the Canadian stock market. International Financial Markets, Institutions and Money, 14, 313-328. http://dx.doi.org/10.1016/j.intfin.2003.09.001

Lambert, R., Leuz, C. \& Verrecchia, R. (2007). Accounting information, disclosure, and the cost of capital. Journal of Accounting Research, 45, 385-420. http://dx.doi.org/10.1111/j.1475-679X.2007.00238.x

Lambert, R., Leuz, C. \& Verrecchia, R. (2012). Information asymmetry, information precision, and the cost of capital. Review of Finance 16, 1-29. http://dx.doi.org/10.1093/rof/rfr014

Lambert, R. \& Verrecchia, R. (2014). Information, illiquidity, and cost of capital. Contemporary Accounting Research 32, 438-454. http://dx.doi.org/10.1111/1911-3846.12078

Leuz, C., Nanda, D. \& Wysocki, P. (2003). Earnings management and investor protection: An international comparison. Journal of Financial Economics 69, 505-527. http://dx.doi.org/10.1016/S0304-405X(03)00121-1

Lintner, J. (1965). Security prices, risk, and maximal gains from diversification. Journal of Finance, 20, 587-615.

Liu, W. (2006). A liquidity-augmented capital asset pricing model. Journal of Financial Economics, 82, 631-671. http://dx.doi.org/10.1016/j.jfineco.2005.10.001 
Mashruwala, C. \& Mashruwala, S. (2011). The pricing of accruals quality: January versus the rest of the year. The Accounting Review, 86, 1349-1381. http://dx.doi.org/10.2308/accr-10035

McNichols, M. (2002). Discussion of The quality of accruals and earnings: the role of accrual estimation errors. The Accounting Review, 77 (Supplement), 61-69. http://dx.doi.org/10.2308/accr.2002.77.s-1.61

$\mathrm{Ng}$, J. (2011). The effect of information quality on liquidity risk. Journal of Accounting and Economics, 52, 126-143. http://dx.doi.org/10.1016/j.jacceco.2011.03.004

Papanastasopoulos, G. (2014). Accounting accruals and stock returns: Evidence from European equity markets. European Accounting Review, 23, 729-768. http://dx.doi.org/10.1080/09638180.2014.882264

Pastor, L. \& Stambaugh, R. (2003). Liquidity risk and expected stock returns. Journal of Political Economy, 111, 642-685. http://dx.doi.org/10.1086/374184

Petkova, R. (2006). Do the Fama-French factors proxy for innovations in predictive variables? Journal of Finance, 61, 581-612. http://dx.doi.org/10.1111/j.1540-6261.2006.00849.x

Roll, R. (1983). Vas ist das? The turn-of-the-year effect and the return premia of small firms. Journal of Portfolio Management, 9, 18-28. http://dx.doi.org/10.3905/jpm.1983.18

Sharpe, W. (1964). Capital asset prices: A theory of market equilibrium under conditions of risk. Journal of Finance, $19,425-442$.

\section{Notes}

Note 1 . The reason why size and book-to-market (the second and third factors) were added to the covariance of a firm's return with the return of the market portfolio (market beta, i.e. the first factor) is that the latter seems to have little relation to realized returns despite the predictions of the Sharpe (1964)-Lintner (1965) capital asset pricing model (Fama \& French, 1993, p. 3).

Note 2. The inconsistency with FLOS, who show the opposite result, may be due to sample differences : one of Ng's (2011) measures of information quality is analyst forecast dispersion, which requires each firm to be followed by at least three financial analysts and biases his sample toward large firms.

Note 3. Because TSX firms are larger than TSXV firms, Group B has a smaller number of firms but a greater proportion of total market capitalization than Group S. For example, on July 1, 2014, Group B (S) contained 516 (2115) firms, representing 97.5\% (2.5\%) of total market capitalization in Canada.

Note 4. As in Amihud (2002), Pastor and Stambaugh (2003) and Liu (2006), I use equally-weighted portfolios because the liquidity factor would otherwise be dominated by large-cap highly liquid stocks.

Note 5 . The portfolios are gradually rebalanced over six months, i.e. each month, $5 / 6^{\text {ths }}$ of the portfolio remain the same while the oldest $1 / 6^{\text {th }}$ is replaced.

Note 6. Because accruals and cash flows are measured with error when the balance sheet method is used (Hribar \& Collins, 2002), I construct an alternative figure derived from cash flow statement data $\left(A Q_{C F}\right)$ and obtain its corresponding factor $A Q F_{C F}$. Under this alternative, I define $C F O$ as Compustat's $O A N C F$ deflated by average assets, I solve for $T C A$ in Equation (6), and all other steps are the same as before. Results are qualitatively similar to those with the balance sheet-based $A Q F$.

Note 7. Firms in the top deciles of $A Q$ are considered low quality because more unpredictable accruals lead to a higher number for $A Q$. Also, following TSXV filing requirements, data are deemed available on the first day of the fifth month after the end of the fiscal year.

Note 8. I use CSHO from the Compustat North America Fundamentals Annual database when CSHOM is missing, as this variable is unavailable before 1998 and coverage is spotty prior to 2002. The correlation between $C S H O$ and CSHOM when both variables are available is 0.99 .

Note 9. $A Q_{t}$ uses operating cash flow estimates from $C F O_{t-6}$ to $C F O_{t}$ (7 years) but $C F O_{t-6}$ is derived from $T C A_{t-6}$ (see Equation (7)), which is based on changes in noncash working capital between $t-7$ and $t-6$. 
Note 10. Two main factors explain the large number of firm-month observations without a corresponding firm-year observations. First, over 1500 Canadian firms on Compustat Security have no accounting data at all in the North America Fundamentals database. Second, over $65 \%$ of the 3379 firms with accounting data have a time series shorter than the eight years required to calculate $A Q$.

Note 11. All continuous variables are winsorized at the 1st and 99th percentiles. Market data are from Compustat North America Security Monthly (CS), and accounting data are from Compustat North America Fundamentals Annual (CF). RET is the monthly stock return (CS: TRTIM). ZEROVOL is the number of zero-volume days during the month $(C S H T R D=0)$. TURN is the sum of daily turnover during the month $(C S H T R D / C S H O M)$. MV is share price times shares outstanding $\left(P R C C{ }^{*} C S H O M\right)$. $A Q$ is accrual quality; see subsection 3.4 for calculation details. GROWTH is the year-over-year sales growth (CF: based on SALE). $\sigma C F O)(\sigma(S A L E S))$ is the five-year standard deviation of cash flows from operations (sales) deflated by total assets. $\log (O P C Y C L E)$ is the natural logarithm of the number of days of the firm's estimated operating cycle (360 times average receivables divided by sales, plus 360 times average inventory divided by cost of goods sold for manufacturing and retail companies). LOSSYRS is the proportion of years in the last five years with a negative income before discontinued operations $(I B)$.

Note 12 . A *** (**, *) next to $t$-stat represents statistical significance at the $1 \%(5 \%, 10 \%)$ level.

Note 13. An untabulated decomposition of returns between the long (LL) and short (HL) legs of LIQ shows that the overwhelming majority of $L I Q$ is driven by the long side of the trading strategy : the $L L$ portfolio returns $4.63 \%$ per month on average while $H L$ returns $0.82 \%$ per month.

Note 14. All correlation coefficients are significantly different than zero at the $10 \%$ level.

Note 15. Amihud (2002) documents that the return spread between illiquid and liquid stocks is smaller, but still significant, when January is excluded.

Note 16. Berges, McConnell and Schlarbaum (1984), Athanassakos (1992) and L'Her, Masmoudi and Suret (2004) provide evidence on the January effect in Canada. L'Her et al. (2004) covers the longest and most recent time period; their sample period ends in April 2001.

Note 17. All correlation coefficients are significantly different than zero at the $10 \%$ level, except the negative coefficient between $L I Q$ and $A Q F$ in January, which is insignificant.

Note 18. Results are similar when five-year rolling windows are used for beta estimation.

Note 19. FLOS show that both innate and discretionary components of $A Q$ are priced in the same direction, but that the innate component is by far the most important. 